\title{
Balanced Scorecard as a Control Tool of the National Security Strategy
}

\author{
Aneta Nowakowska-Krystman *
}

\section{Introduction}

The Nash Equilibrium assumes that countries can reach the state of equilibrium only when none of them stands out in any special way. This, along with the fact that some countries consciously make other countries poorer on their own path to developmentnonetheless giving them compensation exceeding the suffered loss (the Kaldor-Hicks Efficiency) - still results in more dynamic development in the benefiting countries than in the losing countries. This leads to discrepancies in the dynamics of different countries' development, and provides one of the explanations for the existence of social unrest. However, the existence of threats resulting from differences in the level of development between countries is one of many causes that bears upon the issue of security, with regard to individual states as well as regions, and in fact the entire world.

All people intuitively understand the issue of security; moreover, most people agree on the importance of the problem. Security is the basic need of individuals, social groups - in fact, of any subject, including a nation. (For the purposes of this article, we will refer to all of these subjects as the beneficiaries of security.) It is associated with the certainty of existence, possession, functioning, and development. The problem is that security is not a state that can simply be achieved once and then sustained forever; rather, it requires constant actions to be taken in order to provide an acceptable level of security. ${ }^{1}$ Security depends on many factors in both the external and the internal environment. The analysis of these factors requires a constant control, and any conclusions that are drawn constitute a basis for actions which themselves must also be controlled. The control also takes into account the effects of actions taken and performed. It should be noted that when discussing control one can have in mind a variety of aspects (Figure 1). The most simplified definition of control assumes that this is the process of comparing the required state and the real state.

There is a tight bond between control and planning, since control enables one to measure progress toward the achievement of specific goals and permits the optional adjustment of the initial plan. I have attempted in this essay to explain the problem of controlling the obtained result. The simplified definition of control has been applied here, however, with a broader scope that flows from the applied methodology, which is based on the Balanced Scorecard (BSC) concept. It stems from the attempt to present the pos-

\footnotetext{
Aneta Nowakowska-Krystman received her Ph.D. from Warsaw University. Presently, she is an adjunct faculty member in the Institute of Management of Poland's National Defense University. She is interested in issues of management, and in particular, strategic analysis, including the construction and implementation of strategies.

1 Adam D. Rotfeld, Europejski system bezpieczeństwa in statu nascendi (Warsaw: PISM Publishing House, 1990), 5.
} 
sibilities of BSC application in the control of strategy implementation in the bodies of government administration following the example of the national security strategy. Thus, the thesis is based on one of the most popular tools that is used in the planning, implementation, and control of strategy: the Balanced Scorecard. It investigates the process of strategic management from the cause-effect perspective, and deals with the correlation between the chosen strategy and certain actions with indications of how to control their results through the use of carefully chosen quantitative and qualitative indicators. However, the scorecard does not force the employees and organizational bodies to strictly follow the plan set in advance. Thus it is treated as a system of communication, information exchange, and learning, and not as a system of control. ${ }^{2}$ The thesis, however, uses the tool in order to show the control possibilities available that will help achieve the strategic goals of the national security strategy.

Strategic supervision

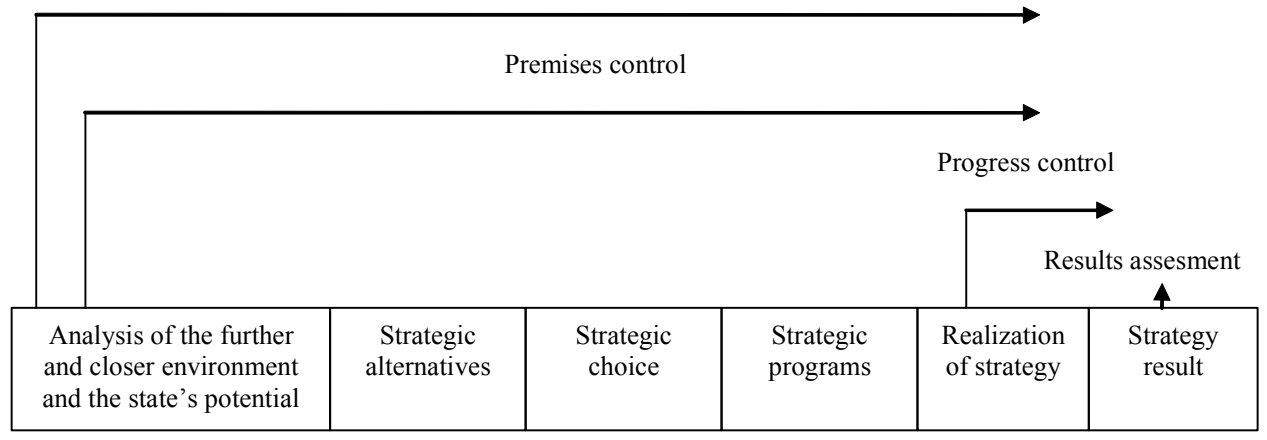

Figure 1: Types of Strategic Control. ${ }^{3}$

\section{National Security Strategy}

Strategy cannot be limited to the general view of the executive. In the classic meaning, it is treated as the method by which the set strategic goals are realized. ${ }^{4}$ Having said that, it is worth emphasizing that strategic goals, in case of the national security strategy, must first of all focus on satisfying the needs of beneficiaries in the realm of security.

2 Robert S. Kaplan and David P. Norton, Strategiczna karta wyników, Jak przełożyć strategię na działanie (Warsaw: PWN, 2001), 42.

3 Based on T. Gołębiowski, Zarządzanie strategiczne. Planowanie i kontrola (Warsaw: Difin, 2001).

4 See Z. Drążek and B. Niemczynowicz, Zarządzanie strategiczne przedsiębiorstwem (Warsaw: PWE, 2003), 27; M. Rajzer, Strategie dywersyfikacji przedsiębiorstw (Warsaw: PWE, 2001), 13; S. Tilles, "How to Evaluate Corporate Strategy," Harvard Business Review 41 (July-August 1963): 111-121; M. Marchesnay, Zarządzanie strategiczne. Geneza i rozwój (Warsaw: Politext, 1994), 17. 
The definition of security, and as a natural consequence the strategic goals, depend to a great extent on personal opinion; moreover, the definitions provided in much of the literature are not mutually exclusive. In the traditional realist approach to the subject of security, the military is the dominant factor. This means that maintaining military security is a priority for the state, which implies the need to grow in power (military power, in particular). A liberal paradigm proves that security does not only refer to countries, but also to interior actors (individuals, social groups). In the process of security analysis, the following aspects were taken into consideration, among others: political, economic, social, cultural, ideological, and ecological. Neo-Marxist theory places particular emphasis on economic issues, with particular reference to the propertied class, since the state mainly realizes their goals. In this view, the key subjects of security are not countries but individuals with certain property in their disposal. Constructionism, on the other hand, defines security through such aspects as ideas and values. ${ }^{5}$

Therefore, national security emphasizes the protection of a country's interests as a whole, as well as the interests of the society and its constituents, including individuals. Thus, security consists of: ${ }^{6}$

- The elimination of both external dangers and internal weaknesses (negative activities)

- The assurance of the survival, territorial integrity, functioning, and free development of a country and its people (positive activities).

The above can lead to a definition of security as a balance between external and internal, current and potential hazards, and the existence of a counteraction efficient enough to ensure the development of a country and its people. It means that the interior potential and activities allowing a nation to make use of external resources must be coordinated in order to serve the national interest, keeping in mind the fact that the latter factor results from national and international determinants.

In order to provide security for different beneficiaries, there is a need to develop a methodology of conduct. Looking at the issue as a process, it can be presented as is shown in Figure 2 below. The main focus here is on the realization of security, which is achieved on the basis of rules that have been worked out through strategic management.

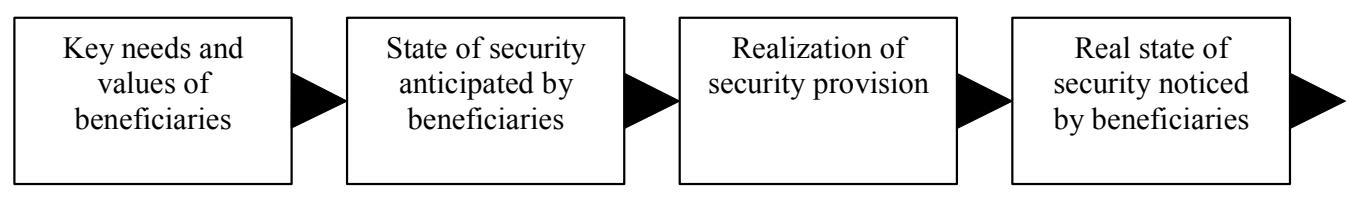

Figure 2: Process Approach to Security.

5 J. Zając, "Bezpieczeństwo - aspekty terminologiczne," in Wspótczesny wymiar bezpieczeństwa. Między teorią a praktyka, ed. J. Pawłowski (Warsaw: RWO, 2011), 18.

6 Ibid., 19. 
The rules of security provision should be entailed in a strategy, in our case the national security strategy. Such a document can be defined as combining the art and science of development with the usage and coordination of national resources in order to achieve goals that contribute to national security. ${ }^{7}$ Thus, strategy implementation is the process of the search for resources which, when used properly, allow a state to achieve its strategic goals. Therefore, it must focus on: ${ }^{8}$

- The development and adjustment of organizational structures to the chosen strategy

- Introduction and sustenance of necessary functions in the activity performed for the accepted strategy to be effectively realized

- The monitoring of particular stages of strategy implementation

- Assessment of the results.

The control of realization as well as the assessment of the results should lead to conclusions and the introduction of activities to correct the shortcomings (Figure 2).

The development and creation of strategy can be based on the balanced scorecard methodology. In such a case, the process of national security strategic management can be depicted as in Figure 3.

The project of strategy commences with setting a vision and elaborating a mission. The vision and mission are crystallized, and as a result strategic goals can be developed, subject to the national interest. ${ }^{9}$ The goals can be presented in the form of a "Goal

7 Compare to Dictionary of Military and Associated Terms, Joint Publication 1-02 (Washington, D.C.: U.S. Department of Defense, 2001), 358.

8 E. Urbanowska-Sojkin, P. Banaszyk, and H. Witczak, Zarządzanie strategiczne przedsiębiorstwem (Warsaw: PWE, 2007), 11.

9 National interest is not explicitly defined in the literature. The advocates of political realism define it as the synonym for survival, security, power, and its derivatives. The authors of a Brookings Institution study defined national interest as "a set of general and stable goals being the object of state activity." The mentioned goals lead to the direct goals, which consequently become tasks to be realized. Others have defined national interest prospectively, defining it as a set of goals which the nation declares to realize in the international relations. In the descriptive meaning, national interest refers to goals realized in a given period of time. Lerce and Said looked at the national interest from the perspective of a final goal, long term goals, mid-term goals, direct goals and political action. Brower suggested replacing the term "national interest" with such notions as: general goals, specific goals or strategies. Schleicher went even further, and rejected the term "national interest" in favor of "basic goals" and "derived direct goals." The representative of neorealist theory, G. Modelski, suggested departing from the notion of national interest, which assumes one type of community, and replacing it with "state interest." State interests are "demands, wishes and desires concerning the behaviour of other countries, they are formulated to be later realized by politicians." Thus, interests articulate goals, and goals shape interests. Therefore, they are correlated. Another neorealist, J. Frankel, remained faithful to the concept of national interest, and distinguished three levels: aspiring, operational, and polemic. See R. Zięba, "Bezpieczeństwo jako cel polityki państwa: aspekty teoretyczne," Wspótczesny wymiar bezpieczeństwa. Między teoria a praktyka, ed. J. Pawłowski (Warsaw: 
Tree." Strategic goals are realized through strategic tasks. They can be ascribed to certain positions, units, or people. Last but not least, it is necessary to set measures that will allow policy makers to assess the goals' realization (see Fig. 4). Vital issues in order to realize the mission, national interests, and goals include: ways to complete the mission; ways to achieve the goals; and preferences in the choice of resources.

To sum up, the analysis of the present state of security focuses on different subjects, individuals, social groups, institutions, organizations, systems, and countries. The attitude, whose expectations should be satisfied by the country, has been changing with the passing of time. Thus, the analysis needs refer to different aspects of security, including political, economic, cultural, and military security - that is, it must consider security from the perspective of subject hazards.

Establishing a national security strategy is a process. It calls for a sequence of activities performed by a country in order to provide national security for a long period of time, taking into consideration different perspectives. It means that the state attempts to sustain and develop national power ${ }^{10}$ to be able to counteract all hazards in certain surroundings, having at its disposal certain domestic resources as well as the necessary external support. ${ }^{11}$

The acceptance of the methodology of a strategic Balanced Scorecard can be helpful in the preparation of the formula of strategy creation, assuming that a strategy is a process that allows one to move from vision to tasks that result from the establishment of measurable goals. Any sector that provides services to society is expected to communicate in particular the vision, mission, goals, and measures that will allow the polity to assess its performance. The provision of such services is a premise for the existence of the state. It is worth adding that the BSC is used not only to explain and communicate a strategy - it is also a tool of strategy management. Thus, it is aimed at developing a system of strategic management. ${ }^{12}$

\section{Measurement of National Security Strategic Goals}

It is vital to determine the strategic goals of national security and the measures that are related to them. In our case, strategic goals are perceived as the future desired state or

RWO, 2011), 22-24; and G. Modelski, A Theory of Foreign Policy (London: Praeger, 1962), $70-72$.

The division of interests varies in different countries. In Poland, they are referred to as: vital, important, essential, etc. National interests can be also examined in two dimensions: absolute and relative. Absolute national interest is connected with the security of citizens' lives, survival of the nation and the country. Relative national interest stems from the quality of citizens' lives and the functioning of the country. They are adjusted to realization through the formulation of goals that act as an incentive for the country to take action, including activities for the provision of security. See R. Zięba, "Bezpieczeństwo jako cel polityki państwa."

10 H. J. Morgentau, in Decyzje polityczne. Elementy teorii (Warsaw: A. Bodnar, 1985), 220.

11 See Alfred D. Chandler, Strategy and Structure in History of the American Enterprise (Cambridge, MA: Harvard University Press, 1992), 14.

12 Kaplan and Norton, Strategiczna karta wyników, 19, 171. 


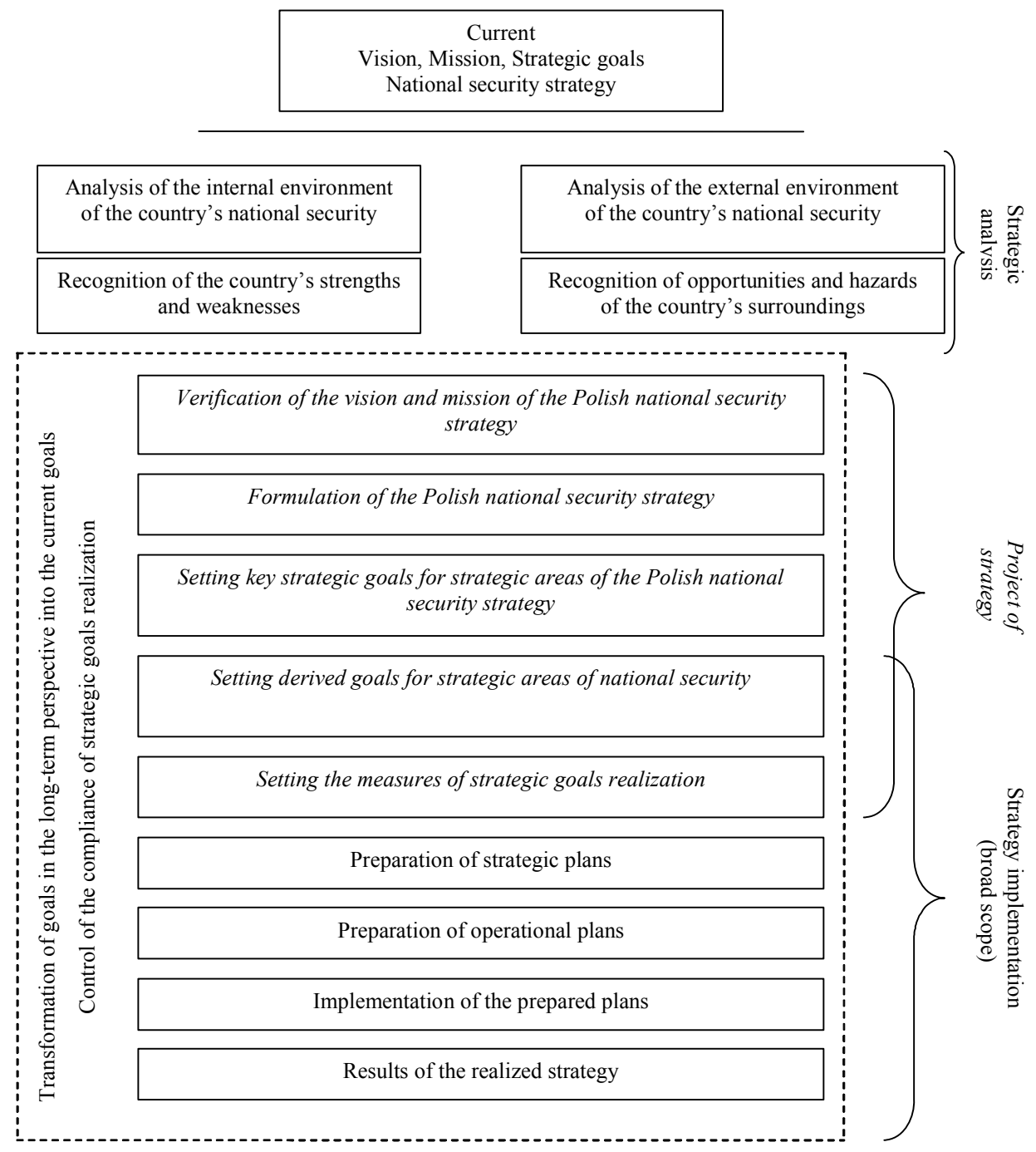

Figure 3: Process of Strategic Management of National Security on the Basis of the BSC Concept. $^{13}$

13 Based on D. A. Decenzo, Podstawy zarządzania (Warsaw: PWE, 2002), 146; K. Obłój, Strategia sukcesu firmy (Warsaw: PWE, 2000), 34; E. Urbanowska-Sojkin, P. Banaszyk, and H. Witczak, Zarzadzanie strategiczne przedsiębiorstwem (Warsaw: PWE, 2007), 242; and T. Gołębiowski, Zarządzanie strategiczne. Planowanie i kontrola (Warsaw: Difin, 2001). 

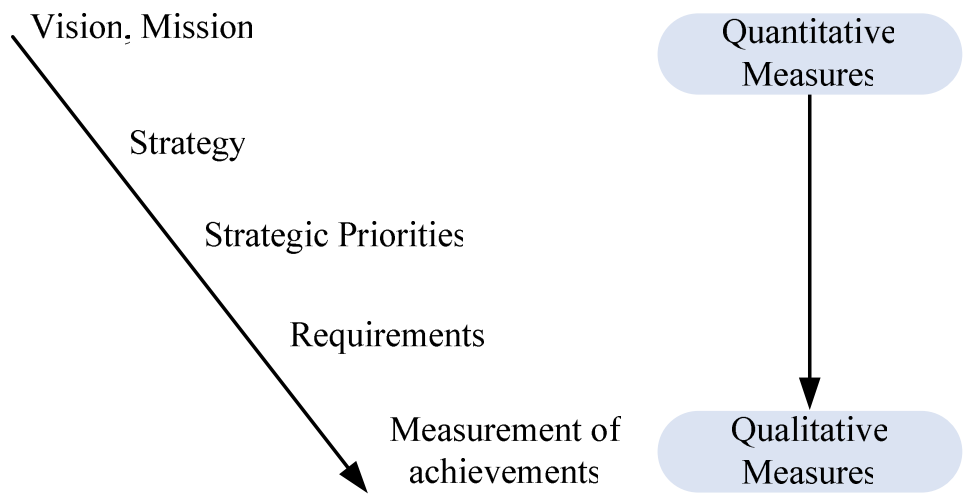

Figure 4: Strategy in Measurables. ${ }^{14}$

result of the country's activity in an isolated strategic area of national security. The National Security Strategy of the Republic of Poland of 2007 distinguishes eight strategic areas (see Table 2, Column 1). The general strategic goals in the scope of national security are delineated by the Constitution of the Republic of Poland of $1997,{ }^{15}$ and are described in more detail by the national security strategy that is currently in force. ${ }^{16}$ Later, strategic goals should be translated into operational goals through the methodology of management by objectives with the use of the BSC.

The Strategic Balanced Scorecard is a management technique that, according to significant research, is effective both in private businesses as well as in institutions that provide public services. Since its emergence as a management theory in the 1980s, it has become one of the most widely used management methods in the world. ${ }^{17}$ Robert Kaplan and David Norton developed the Balanced Scorecard to satisfy the needs of an organization to effectively monitor the effects of strategy realization. It was an attempt to search for solutions to the problem of subjects' failures in the implementation and realization of their accepted strategies. The goal of the BSC was the translation of lofty and, at the same time, general formulations used in organizational vision and mission statements into a language comprehensible to junior managers through the use of a system of cascading objectives. Thus, a strategy was translated into operational goals, tasks, action, and activities, with the use of a set of measures, so that everyone could consciously contribute to the success of the subject (see Figure 5).

14 Based on J. Czuchnowski, Balanced Scorecard (Gdańsk, 2002); available at www.zie.pg.gda.pl/ zzti/dydaktyka/strategie_informatyzacji/si_bsc_wyklad.pdf.

15 Bezpieczeństwo Narodowe Polski w XXI wieku (Warsaw: Bellona, 2006), 160, 171.

16 Strategia bezpieczeństwa narodowego Rzeczpospolitej Polskiej (Warsaw, 2007), 5-6.

17 See Strategiczna Karta Wyników, available at http://www.bmconsult.pl/karta-wynikow-rsc.html; and Wdrażanie Strategicznej Karty Wyników; available at http://karstans.pl/wdrazaniestrategicznej-karty-wynikow,67,11.html. 


\begin{tabular}{|c|c|c|c|c|c|}
\hline & $\begin{array}{l}\text { Strategic } \\
\text { goals }\end{array}$ & $\begin{array}{c}\text { Units of } \\
\text { measure- } \\
\text { ment }\end{array}$ & $\begin{array}{l}\text { Program of } \\
\text { action }\end{array}$ & $\begin{array}{l}\text { Performed } \\
\text { activities }\end{array}$ & $\begin{array}{l}\text { Extent of goal } \\
\text { realization }\end{array}$ \\
\hline $\begin{array}{l}\text { Financial } \\
\text { perspective }\end{array}$ & \multicolumn{3}{|c|}{$\begin{array}{l}\text { If you are not able to measure it, you } \\
\text { cannot manage it }\end{array}$} & & \\
\hline $\begin{array}{l}\text { Perspective of } \\
\text { beneficiaries }\end{array}$ & & \multicolumn{3}{|c|}{$\begin{array}{l}\text { What can be measured can } \\
\text { be done }\end{array}$} & \\
\hline $\begin{array}{l}\text { Process } \\
\text { perspective }\end{array}$ & & \multicolumn{3}{|c|}{$\begin{array}{l}\text { Activity is a thing that } \\
\text { can be calculated }\end{array}$} & \\
\hline $\begin{array}{l}\text { Potential } \\
\text { perspective }\end{array}$ & & & & \multicolumn{2}{|c|}{$\begin{array}{l}\text { You cannot control } \\
\text { anmeasureable goals }\end{array}$} \\
\hline
\end{tabular}

Figure 5: Idea of Measurable Goals in the Balanced Scorecard. ${ }^{18}$

Measures must be properly chosen and adjusted - only then they can provide information about the current situation of an organization and consequently allow managers to make proper decisions. Therefore, a multidimensional scorecard was created based on measures in four perspectives (see Table 1):

\section{Financial}

2. Customer-based (in our case the term "beneficiary" is applied)

3. Internal processes

4. Potential (also called the perspective of development, increase, improvement, knowledge, innovation).

Authors refer to it as a starting point that can be supplemented depending on the type of organization. (For example, institutions providing public services often analyze their organization from the point of view of social perception.) They suggest a certain sequence to the analysis. It should commence with the beneficiary perspective, since it is their needs that are to be safeguarded. The ability to satisfy needs stems from processes; therefore, the second analyzed perspective should be the perspective of internal processes. Both perspectives are characterized by potential parameters. They are key elements for the effective satisfaction of the beneficiary's needs in the future. Financial measures indicate how the strategy of the subject contributes to its development. It should be noticed that the financial perspective in the case of the subject under consid-

18 Based on Czuchnowski, Balanced Scorecard. 
eration here-a country - is not a goal but a limitation, because expenditures must be limited to the amount foreseen in the budget. ${ }^{19}$

Table 1: Relationship Between Time and the Perspectives of BSC. ${ }^{20}$

\begin{tabular}{|c|c|c|c|}
\hline $\begin{array}{l}\text { Perspec- } \\
\text { tive }\end{array}$ & Characteristics & Goals & $\begin{array}{l}\text { Meas- } \\
\text { ures }\end{array}$ \\
\hline $\begin{array}{l}1 . \\
\text { Financial }\end{array}$ & $\begin{array}{l}\text { Presented through financial measures, which al- } \\
\text { low the assessment of the financial effects of } \\
\text { the implemented strategy. It determines how the } \\
\text { realized strategy influences the economic } \\
\text { condition of the subject, using (among other } \\
\text { indicators) profitability, increases in provided } \\
\text { services, cost of employees in relation to their } \\
\text { effectiveness. }\end{array}$ & $\begin{array}{l}\text { g1 } \\
\text { g2 } \\
\text { g3 }\end{array}$ & $\begin{array}{l}\mathrm{m} 1 \\
\cdots \\
\mathrm{m} 7\end{array}$ \\
\hline $\begin{array}{l}2 . \\
\text { Benefici- } \\
\text { aries }\end{array}$ & $\begin{array}{l}\text { The goal is to determine a market segment in } \\
\text { which the subject intends to provide services. } \\
\text { We use here measures that reflect the role of the } \\
\text { subject in serving beneficiaries (e.g. } \\
\text { individuals, social groups, society). The level of } \\
\text { their satisfaction is conditioned by the time of } \\
\text { delivery, quality, cost, and functional values. }\end{array}$ & $\begin{array}{l}\text { g1 } \\
\text { g2 } \\
\text { g3 }\end{array}$ & $\begin{array}{l}\mathrm{m} 1 \\
\cdots \\
\mathrm{m} 7\end{array}$ \\
\hline $\begin{array}{l}3 . \\
\text { Internal } \\
\text { processes }\end{array}$ & $\begin{array}{l}\text { These are presented through indicators referring } \\
\text { to internal processes that are valuable for the } \\
\text { beneficiary, e.g. internal communication, tech- } \\
\text { nology, workers' effectiveness. }\end{array}$ & $\begin{array}{l}\text { g1 } \\
\text { g2 } \\
\text { g3 }\end{array}$ & $\begin{array}{l}\mathrm{m} 1 \\
\ldots \\
\mathrm{m} 7\end{array}$ \\
\hline $\begin{array}{l}4 . \\
\text { Potential }\end{array}$ & $\begin{array}{l}\text { It presents measures that are the basis for long- } \\
\text { term development and improvement, e.g. im- } \\
\text { provement of a product or services, methods of } \\
\text { operation, broadened functional qualities. }\end{array}$ & $\begin{array}{l}\text { g1 } \\
\text { g2 } \\
\text { g3 }\end{array}$ & $\begin{array}{l}\mathrm{m} 1 \\
\ldots \\
\mathrm{m} 7\end{array}$ \\
\hline
\end{tabular}

In each of the perspectives there is a set of measurable, balanced, long- and shortterm goals, chosen through the consideration of both financial and non-financial measures, that serve as indicators of the effects of operational activities as well as external and internal effectiveness. ${ }^{21}$ Taking into account the range of enumerated perspectives prevents a focus on only a single measure, as all of them have been chosen from a large group of measures and each of them is equally important for enabling management to exert influence on putting strategy into action. In the selection of the measures it is help-

\footnotetext{
19 A. Nowakowska-Krystman, "Strategiczna karta wyników jako narzędzie strategii bezpieczeństwa narodowego," in Strategia bezpieczeństwa narodowego. Część II - praca naukowo20 badawcza, ed. J. Gryz (Warsaw: NDU, 2011), 122.

Ibid.

21 Kaplan and Norton, Strategiczna karta wyników,166-67.
} 
ful to follow the Pareto principle (which holds that 80 percent of the effects result from only 20 percent of the causes). Moreover, it is important that the criteria are compliant with the SMART rule (Specific, Measurable, Ambitious, Realistic, Time-bound). Additionally, they should be characterized by such traits as:

- Directness, which means an exact relationship to the stage of goal realization

- Objectivity, or an unambiguous illustration of the stage of goal realization

- Accuracy, which means that in cases when it is difficult to find a synthetic measure reflecting the stage of goal realization, it is advisable to strive to create a set of different measures.

The Balanced Scorecard includes indicators that can be divided into two groups: trailing indicators, which refer to what has already happened; and leading indicators, which look into the future. Leading indicators often have more of a qualitative than a quantitative character, giving information how things that have happened can influence the subject's functioning in the future. It is important to notice that when more than one indicator has been assigned to one goal, it is necessary to determine whether there is a relation between them of:

- Neutrality: the improvement of one indicator does not have an influence on other indicators

- Complementarity: the improvement of one indicator has a positive influence on the other indicators

- Competitiveness: the improvement of one indicator has a negative influence on the other indicators.

When we determine what are the most useful indicators for the goals that have been set in the eight outlined areas of security of the Republic of Poland (RP) - the areas of security strategy correspond to the areas enumerated in the Poland's National Security Strategy of 2007-we must keep in mind the accepted perspectives (see Figure 7). The perspectives differ from those given in Table 1, and are determined in a different sequence, which stems from the character of the deliberated problem. The modified structure of the Balanced Scorecard includes the following perspectives: ${ }^{22}$

1. Beneficiaries: this perspective mainly concerns the aspiration to satisfy the expectations of the party providing financial assets; the expectations of the parties receiving the services; and taxpayers, in order to gain their support

2. Social benefits: this includes benefits for individuals, social groups, and organizations that result from the activity of bodies providing security in certain areas

22 A. Nowakowska-Krystman, "Strategiczna karta wyników jako narzędzie strategii bezpieczeństwa narodowego," in Strategia bezpieczeństwa narodowego. Część II - praca naukowobadawcza, ed. J. Gryz (Warsaw: NDU, 2011), 129. 


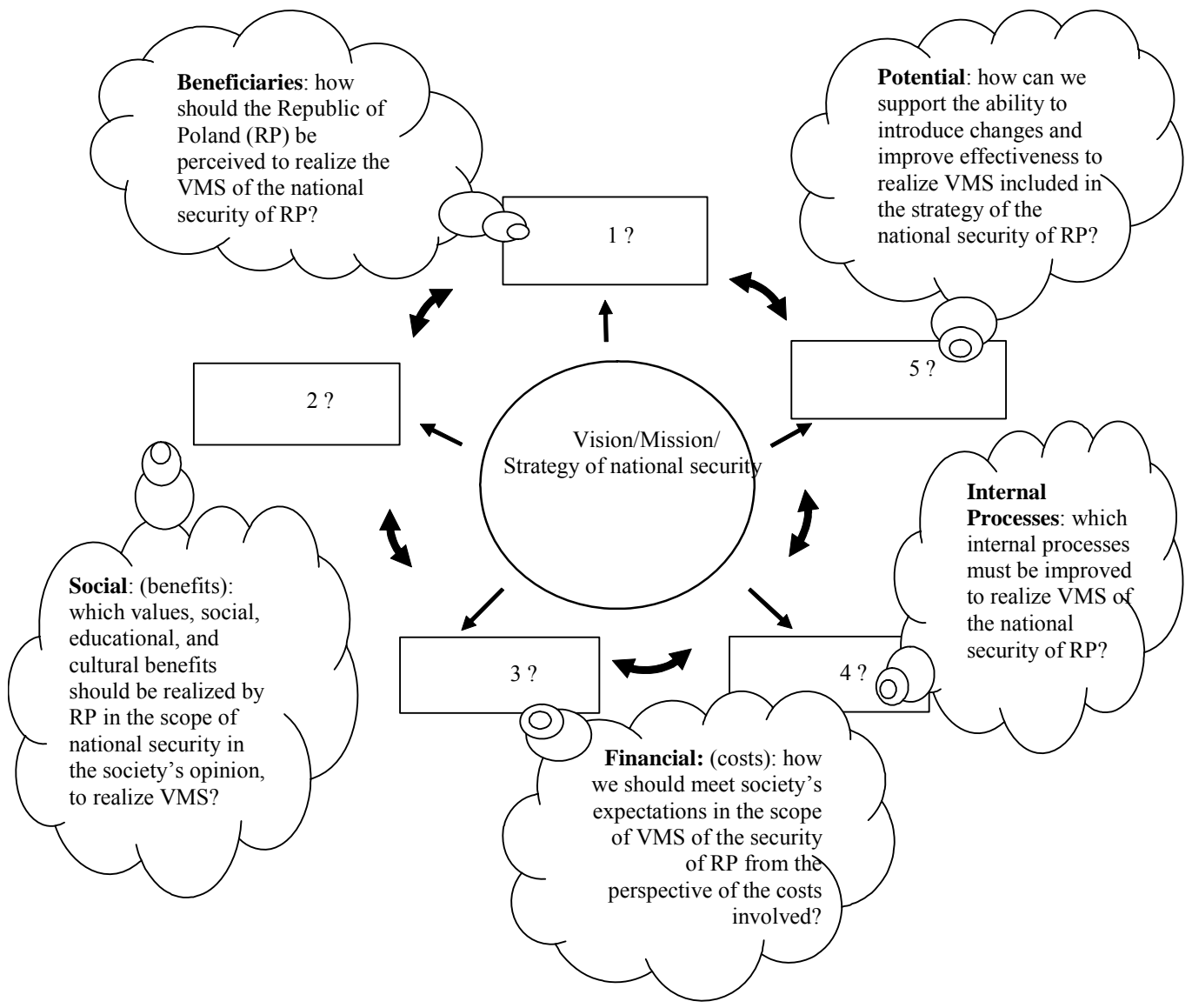

Figure 7: Perspectives of the National Security Strategy in BSC. ${ }^{23}$

3. Financial costs: this perspective considers the expenses of the subject as well as the social costs borne by the society and connected with the subject's activity; the primary goal is to reduce direct costs and social costs necessary for the realization of the vision, mission, and strategy

4. Internal processes: this perspective determines how the subject should master the processes to best satisfy the needs of the beneficiaries

23 A. Nowakowska-Krystman, "Strategiczna karta wyników jako narzędzie strategii bezpieczeństwa narodowego," 130. 
5. Potential: determines how the subject (employees, services) should develop itself in order to realize the intended vision, mission, and national security strategy.

Kaplan and Norton believe that, in the modified structure of the Balanced Scorecard for a subject involved in providing public services, the key role is played by the first three perspectives (i.e. beneficiaries, social benefits, financial costs). Only after the proper goals in those dimensions have been set can one move to identify internal processes and the potential of development (see Figure 8).

Kaplan and Norton emphasize the fact that most scorecards for such subjects expose operational excellence-i.e., they focus on the perspective of internal processes, while placing insufficient focus on beneficiaries. However, in cases of relatively long life-cycles of a given service, the key element of success is the perfection of processes with the needs of customers in mind. ${ }^{24}$ It is worth adding that each of the mentioned perspectives of the Balanced Scorecard may require from four to seven measures. Thus, the number of measures will depend on the number of perspectives. ${ }^{25}$

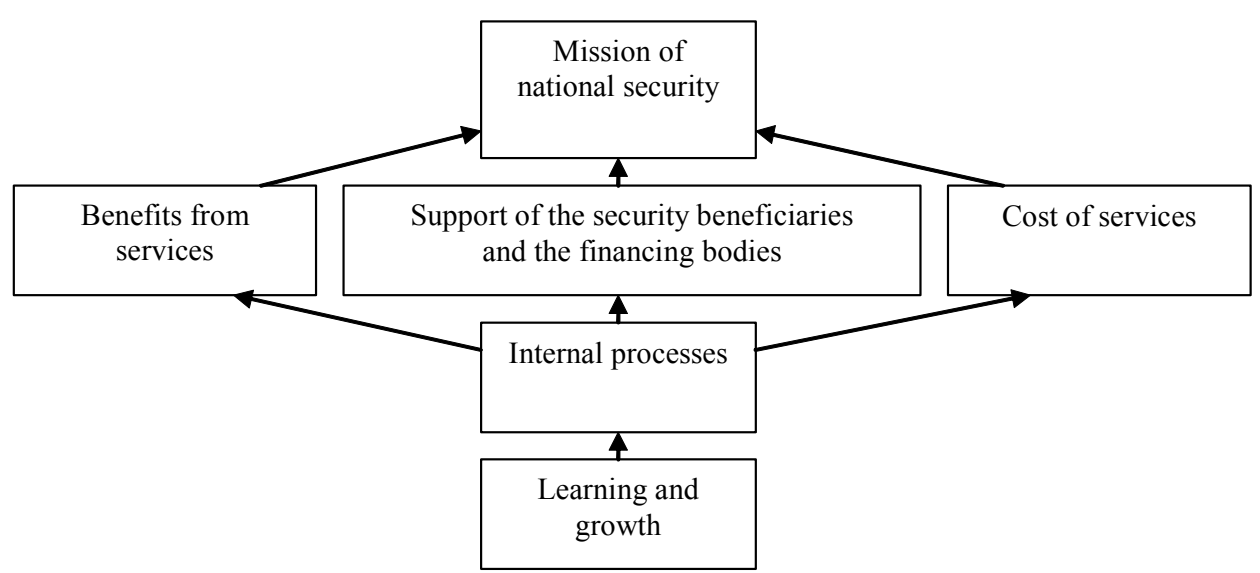

Figure 8: Modified Balanced Scorecard for an Organization Providing Public Services. ${ }^{26}$

To sum up, the idea of the Balanced Scorecard has changed over time. First, it was used as a tool to monitor the process of management, and later as a tool to support strategy implementation. Presently, it is an instrument integrated with a strategy, used to transform long-term strategic goals into current goals. It also enables constant control, but only if the subject's activity and its vision, mission, and strategic goals are in alignment.

24 Kaplan and Norton, Strategiczna karta wyników, 25.

25 Enterprises should use up to 25 strategic measures. See Kaplan and Norton, Strategiczna karta wyników, 151-53.

26

Ibid., 131. 
BSC offers a new model of results measurement and an alternative to traditional systems of measurement and results reporting. Nowadays, financial indicators alone are not sufficient, since along with information about financial results of past activities there is a need for information concerning activities that can have an influence on future financial results. The Balanced Scorecard determines the strategic goals of an organization that go beyond the scope of financial indicators. ${ }^{27}$ Assuming that management is not restricted to the management of material assets, and the measurement of its performance (effectiveness and profitability) is not only based on financial indicators, it is becoming more important to gain and use intellectual resources and non-financial indicators of activity on all levels of management. However, all the measures should be balanced. ${ }^{28}$ Thus, BSC is an attempt to balance financial and non-financial indicators. Hence, it is applied to the operation of organizations that provide public services. Moreover, it strives to balance long- and short-term goals, trailing and leading indicators, and external and internal effectiveness.

It seems that the Balanced Scorecard can be adopted to help realize a nation's security strategy. There is only one question: if the determined perspectives are sufficient to describe the goals of national security, should they be supplemented and exchanged with others? If the answer is yes, which perspectives should replace them? And what indicators should be chosen for the selected perspectives? Those and other issues can be discussed by the representatives of science and practitioners from the security sector.

\section{Control of Strategic Goals of National Security}

The determination of strategic goals is extremely vital, but if it is not followed by implementation and control it may become immaterial. Without control, assumptionseven if they are the proper ones - will not come into force. The Balanced Scorecard may become a tool that is helpful in the effective transition of strategic assumptions onto the executors, which may exert a significant influence on a balanced development of a country.

On the grounds of a document entitled National Security Strategy of the Republic of Poland, eight areas of security have been identified (Table 2, column 1). In accordance with the BSC methodology, we should identify strategic goals (Table 2, columns 3,4 ) and operational goals (Table 2, column 6) in these eight areas, and on this basis derive balanced measures (Table 2, column 11). In order to measure a public task within the distinguished perspectives, we must keep in mind: ${ }^{29}$

1. Gravity (weight): To what extent are goals important in relation to the gravity of needs? (see Table 2, column 5)

27 P. Zob. P. Dżurak, and E.R. Stanoch, “Czy mamy do czynienia z 'rewolucją' systemu pomiaru i oceny działań przedsiębiorstwa?” Controling i Rachunkowość Zarządcza 1 (2001).

28 Kaplan and Norton, Strategiczna karta wyników, 17, 23, 29.

29 A. Nowakowska-Krystman, "Strategiczna karta wyników," 134. 
2. Effectiveness: How much does a task contribute to the achievement of a specific goal? Is the cost/benefit ratio greater than one? Is the system of values applied while the task was being realized acceptable to society?

3. Functionality: Does the task have an impact on the target group of beneficiaries as far as satisfaction of their needs is concerned?

4. Stability: To what extent should we expect changes resulting from the task's completion?

A formula presented in the form of Table 2 and Table 3 should be helpful in the implementation of the given assumptions referring to the structure of the Balanced Scorecard for the preparation, implementation, and control of the national security strategy.

In the process of the realization of goals and tasks in the scope of national security, it is necessary to take political, economic, and military actions that involve specific actors for this purpose-i.e., bodies and institutions that belong to the legislative, executive, and judicial branches, including the Parliament, the President of the Republic of Poland, the Council of Ministers, and central bodies of government administration (see Table 2, column 10) ${ }^{30}$ While setting the scope of responsibility of the various government bodies and institutions, it is important to pay attention to the legal regulations that refer to particular areas of national security and regulate the tasks and competencies of the executive bodies. ${ }^{31}$

In accordance with the methodology developed for the Balanced Scorecard, the realization of a strategy is accompanied by constant monitoring of the compliance of the current activity of a subject with the long-term goals of national security and by assessing the effectiveness of the tasks carried out by various actors. This point of view should be coherent with the attitude towards management control, which determines that in public sector organizations these activities are undertaken as a rule to safeguard the goals and realization of tasks within the guidelines of binding legislation in the most effective, economical, and time-sensitive way. ${ }^{32}$

The assessment of management control and advisory activities supporting a minister in the achievement of his/her goals and tasks is carried out by the internal audit function. The analysis of discrepancies (compliance) in strategy realization can be done separately for each strategic area, and even for each strategic goal, according to the formula presented below (see Table 3). It is very important that the variances that are identified from the accepted values of measures achieved in the planned time (Table 3, column 6, column 7) be analyzed in great detail. For gaps referring to values and time, it is possible to set a deviation; if the variance is higher than that, it will require a correction of strategic assumptions, or a change in the way the subject responsible for the implementation of a given strategic goal functions (Table 3, column 12). Thus it is necessary to determine a critical value. If it is exceeded (the achieved value is lower), it will result in

30 Strategia bezpieczeństwa narodowego Rzeczpospolitej Polskiej (Warsaw, 2007), 21.

31 See Bezpieczeństwo Narodowe Polski w XXI wieku (Warsaw: Bellona, 2006), 171-80.

32 Art. 68 ust. 1 z dnia 27 sierpnia 2009 o finansach publicznych (Dz. U. Nr 157 poz. 1240). 
Table 2: Balanced Scorecard for the Republic of Poland's National Security Strategy

\begin{tabular}{|c|c|c|c|c|c|c|c|c|c|c|}
\hline 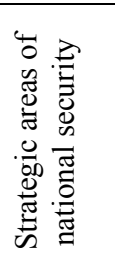 & 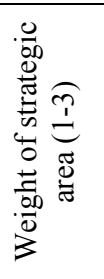 & 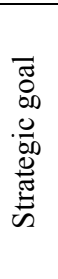 & 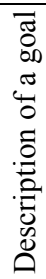 & 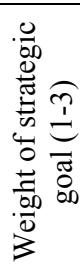 & 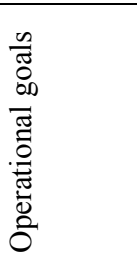 & 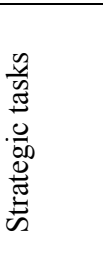 & 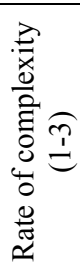 & 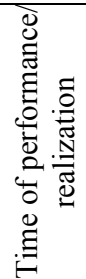 & 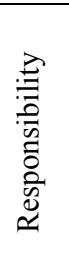 & 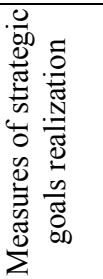 \\
\hline 1. & 2. & 3. & 4. & 5. & 6. & 7. & 8. & 9. & 10. & 11. \\
\hline \multirow{3}{*}{$\begin{array}{l}\text { 1. Ex- } \\
\text { ternal } \\
\text { security }\end{array}$} & \multirow{3}{*}{$\begin{array}{c}\text { weight } \\
1\end{array}$} & g1. & $\ldots$ & ws1 & $\mathrm{g} 1.1, \mathrm{~g} 1.2$ & $\mathrm{t} 1, \mathrm{t} 2, \mathrm{t} 3$ & $\ldots$ & tp1 & M... & w1-w5 \\
\hline & & $\ldots$ & $\ldots$ & $\ldots$ & $\ldots$ & $\ldots$ & $\ldots$ & $\ldots$ & M... & w1-w5 \\
\hline & & gn. & $\ldots$ & wsn & g5.1, g5.2 & $\mathrm{t} 1, \mathrm{t} 2, \mathrm{t} 3$ & $\ldots$ & tp... & M... & w1-w5 \\
\hline \multirow{3}{*}{$\begin{array}{l}\text { 2. Mili- } \\
\text { tary se- } \\
\text { curity }\end{array}$} & \multirow{3}{*}{$\begin{array}{c}\text { weight } \\
2\end{array}$} & g1. & $\ldots$ & ws1 & $\mathrm{g} 1.1, \mathrm{~g} 1.2$ & $\mathrm{t} 1, \mathrm{t} 2, \mathrm{t} 3$ & $\ldots$ & tp... & M... & w1-w5 \\
\hline & & $\ldots$ & $\ldots$ & $\ldots$ & $\ldots$ & $\ldots$ & $\ldots$ & $\ldots$ & M... & w1-w5 \\
\hline & & gn. & $\ldots$ & wsn & g5.1, g5.2 & $\mathrm{t} 1, \mathrm{t} 2, \mathrm{t} 3$ & $\ldots$ & tp... & M... & w1-w5 \\
\hline \multirow{3}{*}{$\begin{array}{l}\text { 3. Inter- } \\
\text { nal se- } \\
\text { curity }\end{array}$} & \multirow{3}{*}{$\begin{array}{c}\text { weight } \\
3\end{array}$} & g1. & $\ldots$ & ws1 & $\mathrm{g} 1.1, \mathrm{~g} 1.2$ & $\mathrm{t} 1, \mathrm{t} 2, \mathrm{t} 3$ & $\ldots$ & tp... & M... & w1-w5 \\
\hline & & $\ldots$ & $\ldots$ & $\ldots$ & $\ldots$ & $\ldots$ & $\ldots$ & $\ldots$ & M... & w1-w5 \\
\hline & & gn. & $\ldots$ & wsn & g5.1, c5.2 & $\mathrm{t} 1, \mathrm{t} 2, \mathrm{t} 3$ & $\ldots$ & tp... & M... & w1-w5 \\
\hline \multirow{3}{*}{$\begin{array}{l}\text { 4. Civic } \\
\text { security }\end{array}$} & \multirow{3}{*}{$\begin{array}{c}\text { weight } \\
4\end{array}$} & g1. & $\ldots$ & ws1 & $\mathrm{g} 1.1, \mathrm{~g} 1.2$ & $\mathrm{t} 1, \mathrm{t} 2, \mathrm{t} 3$ & $\ldots$ & tp... & M... & w1-w5 \\
\hline & & $\ldots$ & $\ldots$ & $\ldots$ & 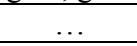 & $\ldots$ & $\ldots$ & $\ldots$ & M... & w1-w5 \\
\hline & & gn. & $\ldots$ & wsn & g5.1, g5.2 & $\mathrm{t} 1, \mathrm{t} 2, \mathrm{t} 3$ & $\ldots$ & tp... & M... & w1-w5 \\
\hline \multirow{3}{*}{$\begin{array}{l}\text {. So- } \\
\text { cial se- } \\
\text { curity }\end{array}$} & \multirow{3}{*}{$\begin{array}{c}\text { weight } \\
5\end{array}$} & g1. & $\ldots$ & ws1 & $\mathrm{g} 1.1, \mathrm{~g} 1.2$ & $\mathrm{t} 1, \mathrm{t} 2, \mathrm{t} 3$ & $\ldots$ & tp... & M... & w1-w5 \\
\hline & & $\ldots$ & $\ldots$ & $\ldots$ & $\ldots$ & $\ldots$ & $\ldots$ & $\ldots$ & M... & w1-w5 \\
\hline & & gn. & $\ldots$ & wsn & g5.1, g5.2 & $\mathrm{t} 1, \mathrm{t} 2, \mathrm{t} 3$ & $\ldots$ & tp... & M... & w1-w5 \\
\hline \multirow{3}{*}{$\begin{array}{l}\text { 6. Eco- } \\
\text { nomic } \\
\text { security }\end{array}$} & \multirow{3}{*}{$\begin{array}{c}\text { weight } \\
6\end{array}$} & g1. & $\ldots$ & ws1 & $\mathrm{g} 1.1, \mathrm{~g} 1.2$ & $\mathrm{t} 1, \mathrm{t} 2, \mathrm{t} 3$ & $\ldots$ & tp... & M... & w1-w5 \\
\hline & & $\ldots$ & $\ldots$ & $\ldots$ & & & $\ldots$ & $\ldots$ & M... & w1-w5 \\
\hline & & $\mathrm{cn}$. & $\ldots$ & wsn & g5.1, g5.2 & $\mathrm{t} 1, \mathrm{t} 2, \mathrm{t} 3$ & $\ldots$ & tp... & M... & w1-w5 \\
\hline \multirow{3}{*}{$\begin{array}{l}\text { 7. Eco- } \\
\text { logical } \\
\text { security }\end{array}$} & \multirow{3}{*}{$\begin{array}{c}\text { weight } \\
7\end{array}$} & g1. & $\ldots$ & ws1 & $\mathrm{g} 1.1, \mathrm{~g} 1.2$ & $\mathrm{t} 1, \mathrm{t} 2, \mathrm{t} 3$ & $\ldots$ & tp... & M... & w1-w5 \\
\hline & & $\ldots$ & $\ldots$ & $\ldots$ & $\ldots$ & $\ldots$ & $\ldots$ & $\ldots$ & M... & w1-w5 \\
\hline & & gn. & $\ldots$ & wsn & g5.1, g5.2 & $\mathrm{t} 1, \mathrm{t} 2, \mathrm{t} 3$ & $\ldots$ & tp... & M... & w1-w5 \\
\hline \multirow{3}{*}{$\begin{array}{l}\text { 8. Info } \\
\text { and } \\
\text { comm } \\
\text { security }\end{array}$} & \multirow{3}{*}{$\begin{array}{c}\text { weight } \\
8\end{array}$} & g1. & $\ldots$ & ws1 & $\mathrm{g} 1.1, \mathrm{~g} 1.2$ & $\mathrm{t} 1, \mathrm{t} 2, \mathrm{t} 3$ & $\ldots$ & tp... & M... & w1-w5 \\
\hline & & $\ldots$ & $\ldots$ & $\ldots$ & $\ldots$ & $\ldots$ & $\ldots$ & $\ldots$ & M... & w1-w5 \\
\hline & & gn. & $\ldots$ & wsn & g5.1, g5.2 & $\mathrm{t} 1, \mathrm{t} 2, \mathrm{t} 3$ & $\ldots$ & tpn & M... & w1-w5 \\
\hline
\end{tabular}

\section{Legend:}

weight1-weight8: weight of strategic areas: ( 1 - other essential, 2 -important, 3 - vital) ws1 ... ws5: weight of strategic goal ( 1 - other essential, 2 - important, 3 - vital)

Complexity of tasks: ( 1 - easy, 2 - complex, 3 - very complex)

Measures of the strategic goal from: w1 -beneficiary perspective; w2 -perspective of social benefits; w3 - financial perspective; w4 - internal process perspective; w5 - the perspective of potential

M - Ministry 
taking definite corrective action through proper channels (Table 3 , columns 10, 11). Therefore, control can exert a significant influence on the decision-making process. ${ }^{33}$

Table 3: Control of the Effect of the National Security Strategy according to Accepted Measures.

\begin{tabular}{|c|c|c|c|c|c|c|c|c|c|c|c|}
\hline \multirow{2}{*}{ 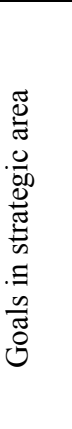 } & \multicolumn{2}{|c|}{ Plan } & \multicolumn{2}{|c|}{ Performance } & \multicolumn{2}{|c|}{ Gap } & \multicolumn{2}{|c|}{$\begin{array}{c}\text { Acceptable } \\
\text { deviations }\end{array}$} & \multicolumn{2}{|c|}{$\begin{array}{c}\text { Critical } \\
\text { values }\end{array}$} & \multirow{2}{*}{ 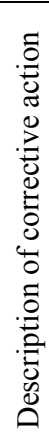 } \\
\hline & 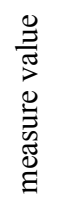 & 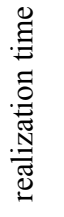 & 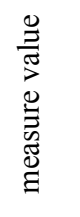 & 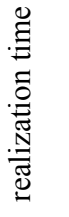 & 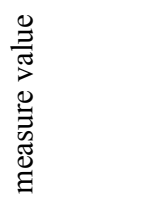 & 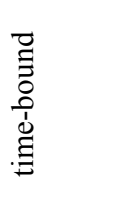 & 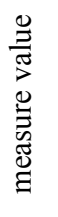 & 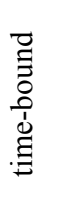 & 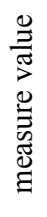 & 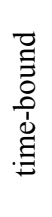 & \\
\hline 1 & 2 & 3 & 4 & 5 & 6 & 7 & 8 & 9 & 10 & 11 & 12 \\
\hline g1. & wp1 & tp1 & ww1 & tw1 & ww1-wp1 & tw1-tp1 & $\ldots$ & $\ldots$ & $\ldots$ & $\ldots$ & ... \\
\hline g2. & wp2 & $\operatorname{tp} 2$ & ww2 & tw2 & ww2-wp2 & $\mathrm{tw} 2-\mathrm{tp} 2$ & $\ldots$ & $\ldots$ & $\ldots$ & $\ldots$ & $\ldots$ \\
\hline g3. & wp3 & tp3 & ww3 & tw3 & ww3-wp3 & tw2-tp2 & $\ldots$ & $\ldots$ & $\ldots$ & $\ldots$ & $\ldots$ \\
\hline
\end{tabular}

In summary, before the Balanced Scorecard was developed, the ability to control compliance with the results achieved from a prepared strategy was limited.$^{34}$ In spite of its broad scope, the Balanced Scorecard does not burden managing units with excess information, due to the selection of a limited number of indicators. Moreover, it is also very important that in the BSC it is possible to create new measures that are better suited to the situation.

The national security strategy is superior to executive strategies. Assuming that the national security strategy is superior, we should decide how detailed it is to be, especially with regard to adjusting measures to fit the set strategic goals. This is because the individuals or bodies responsible for implementing particular executive strategies will bear responsibility for the gaps in goals realization, calculated on the basis of certain measures.

Finally, there is a problem: who should realize the strategy? One can assume that primary responsibility lies with the public administration, whose analysis could be implemented by non-governmental organizations. However, there is still the question of who will assess its implementation, and on the basis of what measures. Those questions

33 A. Nowakowska-Krystman, "Strategiczna karta wyników," 134.

34 See A. Nowakowska-Krystman, "Strategiczna karta wyników." 
are reflected in many aspects of life, and formulating the national security strategy on the basis of the Balanced Scorecard can help to find correct answers.

\section{Conclusions}

From the point of view of the balanced development of a country in the realm of security, the preparation of a document that balances interests in different areas is extremely important. The document should provide guidelines that can be translated into specific goals and activities. A country, while preparing a strategy - including a national security strategy - must have knowledge about the state of both the external and internal environment. Research carried out correctly conditions proper strategic assumptions. The implementation of the Balanced Scorecard in the area of national security management demands the adjustment of a method to the character of a problem. Thus, we can expect that soon we should find on the market publications presenting possibilities to prepare and cascade the Balanced Scorecard, pointing at perspectives, areas, strategic goals and measures, and calculating the rate of their realization for the use by a country.

In conclusion, in the light of the knowledge provided by the subject literature, it seems that the BSC will be an effective form of planning, implementation, and control of a national security strategy. The construction of a Balanced Scorecard for the national security strategy should commence with setting the vision and mission of a country in the scope of security. Then, the effort must be made to prepare a strategy that determines priorities, such as strategic factors of security success, in order to be able to define strategic goals in each of the enumerated areas. Finally, the measures of achievement are chosen within the delineated perspectives. This may present the most significant obstacles, since we need to create such indicators that will measure the rate of realization of a national security vision, which is determined through strategic goals. Thus, the specific character of the subject imposes the necessity to prepare a unique set of indicators used in the process of BSC method application, with reference to each area, within the set perspectives. 


\section{Bibliography}

Bezpieczeństwo Narodowe Polski w XXI wieku. Warsaw: Bellona, 2006.

Chandler, Alfred D.. Strategy and Structure in History of the American Enterprise. Cambridge, MA: Harvard University Press, 1992.

Czuchnowski, J.. Balanced Scorecard. Gdańsk, 2002.

Decenzo, D. A.. Podstawy zarządzania. Warsaw: PWE, 2002.

Drążek, Z., and B. Niemczynowicz. Zarządzanie strategiczne przedsiębiorstwem. Warsaw: PWE, 2003.

Gołębiowski, T.. Zarządzanie strategiczne. Planowanie i kontrola. Warsaw: Difin, 2001. Marchesnay, M.. Zarządzanie strategiczne. Geneza i rozwój. Warsaw: Politext, 1994.

Modelski, G.. A Theory of Foreign Policy. London: Praeger, 1962.

Morgentau, H. J.. Decyzje polityczne. Elementy teorii. Warsaw: A. Bodnar, 1985.

Norton, Robert S. Kaplan. Strategiczna karta wyników, Jak przełożyć strategię na działanie. Warsaw: PWN, 2001.

Nowakowska-Krystman, A.. "Strategiczna karta wyników jako narzędzie strategii bezpieczeństwa narodowego." In Strategia bezpieczeństwa narodowego. Część II praca naukowobadawcza, 122. Warsaw: NDU, 2011.

Obłój, K.. Strategia sukcesu firmy. Warsaw: PWE, 2000.

P. Dżurak, Zob. P., and E.R. Stanoch. "Czy mamy do czynienia z 'rewolucją' systemu pomiaru i oceny działań przedsiębiorstwa?" Controling i Rachunkowość Zarządcza 1 (2001).

Rajzer, M.. Strategie dywersyfikacji przedsiębiorstw. Warsaw: PWE, 2001.

Rotfeld, Adam D.. Europejski system bezpieczeństwa in statu nascendi. Warsaw: PISM Publishing House, 1990.

Strategia bezpieczeństwa narodowego Rzeczpospolitej Polskiej (National Security Strategy of the Republic of Poland). Warsaw: Ministry of National Defense, 2003.

Tilles, S.. "How to Evaluate Corporate Strategy." Harvard Business Review 41 (1963): 111-121.

Zając, J.. "Bezpieczeństwo - aspekty terminologiczne." In Współczesny wymiar bezpieczeństwa. Między teorią a praktyką, 18. Warsaw: RWO, 2011.

Zięba, R.. "Bezpieczeństwo jako cel polityki państwa: aspekty teoretyczne." In Współczesny wymiar bezpieczeństwa. Między teorią a praktyką, 22-24. Warsaw: RWO, 2011. 